\title{
Music of the Hemispheres
}

\author{
Andrew Kirk
}

Can. J. Neurol. Sci. 2009; 36: 531-533

"But will they love us?" asked Peeto, puffing as he caught up.

Badj smiled, shook his head and said, "You can't know whether they'll love you. You can only know which ones will see you."

Peeto tapped Badj lightly on the shoulder and ran ahead. "I hope they'll love us. I hope they'll love us," Peeto sang as he skip-skated across the dewy grass. He kicked a spray of tiny rainbows up into the morning light.

Badj had heard of a place where you could find the ones who'd see you and he knew that sometimes they'd love you too. He hoped that he and Peeto would be loved. It had been a long time since Badj had been loved. "It's not far now," he shouted to Peeto and ran after him.

So far, Dad's been having one of his good mornings. He seems almost himself during breakfast as we talk about the harvest. This year we had to hire out for him to finish in time. He's slowed down a lot and there are so many days now that he has trouble keeping track of what needs to be done. Sometimes he'll just sit and stare for hours at a time. I can't see him maintaining the farm another year. It's hard for me to get time away from the bank and Dale's got his business. There's not much choice but to sell out and move Dad into town. My brother and I can't run a farm from three hours away.

Dad finishes his coffee without spilling any - quite an accomplishment for him these days.

"Time to head into the city for your appointment, Dad."

"Appointment?"

"You know. That's why I drove out here yesterday - to take you to see that doctor this morning. About your memory."

He laughs. On a day like this, it's easy to wonder whether we might be mistaken. Maybe he's okay. But then there are the days when he's so confused, when it can seem like he's not even in there anymore. I almost wish this had been a bad day so the doctor could have seen him at his worst. What if the specialist sends us away with a pat on the back and says there's nothing wrong?

I help Dad on with his jacket. The morning is still cool. The sun isn't even up yet but you can see a glow beyond the wheatstubbled fields. Rosy-fingered dawn, my daughter Laurie would call it. Laurie and her Greek mythology. You have to wonder what kind of a job that kid's going to find with a degree in classics. And now it's not enough to worry about my kids; I have to worry about my dad too.

I take his arm as we walk to the truck, our breath puffing out in little clouds. Just last spring Dad wouldn't have needed help with his jacket. He wouldn't have needed me to hold onto him either. Sometimes now I wonder whether we should be getting him a walker.

Badj and Peeto arrived at the big brick structure. "I don't like these places," said Peeto. "I've been in brick places before and they're not nice at all. They're smelly. You can't even taste the sky in there. And no one glows at all."

"Yeah, but this one's different. They say this is a good place to find the ones that glow a bit, the ones that might be able to see you," said Badj. Peeto hung back, looking doubtful. Badj added, "People who might love us."

"All right," said Peeto. "I'll go inside. But if no one glows, I'm leaving." He stopped at the threshold. "You say there are people in there who'll love us?"

"I told you, I don't know if they'll love us. I don't even know for sure that they'll see us. But it's what I've heard."

"What do they think of us if they don't love us?"

"They don't really think anything. They might think we're children. Even the ones who love us think we're children."

"Yeah? Because we're smaller than them?"

Badj punched him on the shoulder. "No, because we're taller than trees. Of course, because we're small. We're the size of their children."

Peeto tried to punch back but missed when Badj jumped aside. "Maybe that's why some of them love us," said Peeto.

"Maybe. Come on, let's get inside."

All the way into the city, Dad's in good shape. No staring spells. No animals or kids by the side of the road. He's not walking well when we get to the hospital though. It turns out to be a long way

From the Division of Neurology, Royal University Hospital, Saskatoon, SK, Canada.

Received January 12, 2009. Final Revisions Submitted February 26, 2009. Correspondence to: Andrew Kirk, Division of Neurology, Royal University Hospital, 103 Hospital Drive, Saskatoon, Saskatchewan, S7N 0W8, Canada. 
from the parking lot to the memory clinic and I have to get him a wheelchair. Dad doesn't even raise a fuss about it. Just a few months ago he'd never have consented to a wheelchair.

I get him registered with the nurse or secretary or whatever she is. Hell, for all I know she's a doctor too. I don't know how these clinics work. Since Mom died eight years ago, I've managed to steer clear of hospitals. The nurse (secretary?) gives me some questionnaires to fill out and tells us to sit in the hall till it's time to see the doctor. I smile at another family already sitting there filling out papers - a woman a little older than me and a shrunken little woman in a wheelchair. Dad doesn't even look at them. I get started on the forms.

Peeto amused himself taking running slides up and down the halls while Badj looked for those who might see them. Most of the people they passed had that gray look the big ones so often have. None of them glowed. A few of the children almost glowed. You could tell that they could nearly see Badj and Peeto.

"Can we go home yet?" asked Peeto.

"You can go home if you want. We've come all this way and I'm staying till I find someone who can see us."

Peeto stopped his sliding and asked, "What if you don't find any?"

"Let's cross that bridge if we come to it." They turn a corner and Badj points. "Look," he says.

By the time I wheel Dad into the doctor's office, he's in one of his trances as Laurie calls them. His face is a blank as if the lights are on but nobody's home. The specialist turns out to be nearly Dad's age. Dad doesn't respond to the doctor's questions. The doctor asks me for a history of what's been happening this past year or so. "How often does he get like this?" he asks.

"I'm not sure - maybe once or twice a day. Sometimes it's just for a few minutes but sometimes it can last hours. It's hard for me to be sure because I'm in the city and Dad's still out on the farm. Neighbors look in on him and they tell me there are times when he seems just fine - the way he was earlier this morning - and other times when he's like this."

The doctor's holding onto Dad's hand and moving it in a circular motion at the wrist. "Trouble walking too?"

"Yeah. He's really been slowing down. He's had a few falls."

"Does he hallucinate?"

Now how did he know that? "Yes."

"Can you tell me about that?"

"Well, sometimes he'll see animals out the window of his home or beside the road when we're in the car. Sometimes he sees children. One night last month a neighbor came over to check on Dad and found he had blankets all over the kitchen floor to keep the children warm. He thought there were kids in his house and he was trying to look after them. Another time he called me and said he was worried about some little children playing in his front yard. There didn't seem to be anyone with them and he was afraid they were lost. I phoned Dad's neighbor who went over and then called me back and said there were no kids around at all."

"What kids?" asks Dad who seems to be back with us.

"No kids. It's okay, Dad."

"All right."
"How are you doing Mr. Evans?" the doctor asks.

"Not bad. And you?"

"I'm just fine." The doctor smiles. "Any trouble with your memory?"

"No more than most people my age," says Dad with a laugh.

I nod at the doctor as surreptitiously as I can. "Any falls?" he asks.

Dad shakes his head. "Yeah, a few," I say.

The specialist examines Dad for a while and then sends him off for some memory testing and a CT scan of his head. We're to come back and discuss the results later in the day.

At the end of the corridor were two that glowed - an old man and an old woman. Peeto grinned.

"See, I told you," said Badj.

Badj and Peeto advanced slowly down the hall. The old glowman smiled at them and then gradually stood, leaving his graybody behind on his wheeled chair. He stretched and jumped and then called to the old woman who also left her gray-body to follow Badj and Peeto. The four of them chased each other along the corridor. They laughed. Peeto tapped the woman on the knee and shouted, "You're it." She giggled and snatched at him, just missing. The man jumped over Badj and then spun the woman around in a wild dance.

Peeto plucked a brier from the air and cried, "Ceci n'est pas un pipe," as he sent it skittering along the hallway to thud against a young man's foot. The young man scratched his knee. You could see that he was almost aware of the dancing and the shouting. He got up and left the corridor. The four who glowed joined hands.

The nurse calls me back in to discuss things with the doctor. A thick manila envelope sits on his desk. It can't be Dad's test results. There hasn't been time to fill an envelope that full.

"Mr. Evans, the changes you've noticed in your father are typical of a particular illness."

I'm surprised. Can there be other people with all these oddities? "Everything?" I ask.

"Yes - the slowness, the falls, the hallucinations, the memory problems."

"The times when he's not even there?"

"When the music stops?" asks the doctor.

"The music?"

"I like to think of it that way. What is thought after all but the music of the hemispheres? And sometimes in this illness the orchestra takes intermissions."

"So what is it he's got?"

Badj, Peeto, and the two larger people joined hands and stood in a circle on the slippery floor. They looked at each other and then Peeto began the song, his high frail voice bouncing off the bare walls. Badj joined in after the first verse, his voice harmonizing with Peeto's. The old man gave the old woman's hand a squeeze and then started to sing as well, his bass strengthening and swelling the music. The woman fit her harmony in between the man's and the two small ones'. Peeto smiled as he sang. Through the melody he felt loved for the first time in ages. He was grateful to Badj for bringing him here. 
The doctor pushes the thick brown envelope across his desk toward me. He plants his palm on it and says, "Here's some information about Lewy body dementia."

"That's what Dad has?"

"Yes, I believe so. It's characterized by most of the things you've noticed about your father."

"Can it be treated?"

"It can't be cured or stopped in its tracks. It's a progressive degenerative disorder. But there are some things we can do that sometimes help."

The specialist tells me about a medication he'd like to try and I leave his examining room with a prescription and an appointment to bring Dad back in six weeks to assess his response. Dad doesn't even move when I clasp his shoulder. He's off in another world again. I wheel him along the corridor toward the exit.
The song ended. The old man gave Badj, Peeto, and the woman a smile and then slid off to catch up to the wheeled chair and sink back into his gray-body. Peeto could see that the man would rather have stayed but he'd fast have faded without his gray-body nearby.

As I'm helping Dad into the truck, he turns and raises his hand as if waving to someone. He stumbles and nearly hits his head on the door. "You all right, Dad?"

He mutters something that sounds like, "Those glow-boys."

"What, Dad?"

"Nothing." Dad just smiles.

Once the woman had left too, Badj and Peeto headed home, skate-skipping through the long grass of the meadow path that led them to their own field. Their hearts were full. 